Jurnal Civics: Media Kajian Kewarganegaraan
https://journal.uny.ac.id/index.php/civics/index
$1829-5789$ (print)
$2541-1918$ (online)

\title{
Persepsi mahasiswa terhadap kemunculan berita bohong di media sosial
}

\author{
Totok Suyanto $^{\text {a }}$, Ketut Prasetyo ${ }^{\text {b }}$, Prasetyo Isbandono ${ }^{\text {c }}$, Ita Mardiani Zain ${ }^{\text {4 }}$, Iman \\ Pasu Purba ${ }^{\text {e } 5}$, Gading Gamaputra ${ }^{\text {f } 6}$ \\ a, b, c, d, e, f Fakultas Ilmu Sosial dan Hukum, Universitas Negeri surabaya, Surabaya, Indonesia \\ 1,2,3,4,5,6 totoksuyanto@unesa.ac.id*; ketutprasetyo@unesa.ac.id; prasetyoisbandono@unesa.ac.id; \\ itazain@unesa.ac.id; imanpurba@unesa.ac.id; gadinggamaputra@unesa.ac.id \\ *korespondensi penulis
}

\begin{tabular}{|c|c|}
\hline Informasi artikel & ABSTRAK \\
\hline \begin{tabular}{ll} 
Sejarah artikel: & \\
Diterima & $: 10-12-2017$ \\
Revisi & $: 01-02-2018$ \\
Dipublikasikan & $: 31-05-2018$ \\
Kata kunci: & \\
Berita bohong (hoax) \\
Media sosial \\
\multicolumn{2}{l}{ Literasi kewarganegaraan }
\end{tabular} & $\begin{array}{l}\text { Di era demokratisasi saat ini yang bercirikan adanya kebebasan } \\
\text { berpendapat setiap warga baik secara lisan ataupun tertulis, maka } \\
\text { fenomena hoax menjadi satu hal yang harus menjadi perhatian } \\
\text { bersama. Desain penelitian yang digunakan adalah penelitian } \\
\text { survey. Proses penyebaran berita dalam media sosial banyak } \\
\text { melibatkan kaum perempuan. Hanya sebagian kecil saja yang } \\
\text { mengakui sering mendapatkan berita-berita hoax tentang suku, } \\
\text { agama, ras, dan antar golongan (SARA). Dengan demikian, } \\
\text { maraknya penyebaran berita hoax di media sosial merupakan satu } \\
\text { bentuk pembodohan masyarakat dan respons terhadap } \\
\text { kemunculan berita hoax dengan cara melakukan tindakan } \\
\text { perlawanan. }\end{array}$ \\
\hline $\begin{array}{l}\text { Keywords: } \\
\text { Hoax } \\
\text { Social media, } \\
\text { Civic Literacy }\end{array}$ & $\begin{array}{l}\text { ABSTRACT } \\
\text { The student perception of hoax in social media. In this } \\
\text { democratization era characterized by the freedom of speech } \\
\text { belongs to every citizen both written and spoken, the hoax should } \\
\text { be considered seriously. It was a survey research. The spread of } \\
\text { news through social media was conducted mostly by women. It } \\
\text { was only small numbers who reported that they had received hoax } \\
\text { relating SARA. Therefore, the spreading of hoax through social } \\
\text { media is a kind of fooling and their response is through counter- } \\
\text { narrative. }\end{array}$ \\
\hline
\end{tabular}

Copyright $\odot 2018$ Totok Suyanto, dkk

\section{Pendahuluan}

Model komunikasi manusia mengalami transformasi dari yang sifatnya langsung (face to face communication) berubah menjadi komunikasi tidak langsung yang sifatnya membutuhkan media sebagai instrumen dalam melakukan praktik komunikasi. Komunikasi model ini bersifat tak terbatas baik oleh jarak dan waktu, dan bersifat virtual. Perkembangan teknologi komunikasi dan informasi memberikan andil dan sumbangsih yang signifikan bagi proses transformasi tersebut. Bahkan kecenderungan terkini pola komunikasi berubah seiring perkembangan teknologi komunikasi dari teknologi yang bersifat analog berubah menjadi teknologi digital. Maka komunikasi di kehidupan modern tidak hanya mengandalkan komunikasi face to face yang bersifat dua arah, namun komunikasi yang terjadi multi arah dan bisa berlangsung secara cepat dan massif.

Kehadiran mesin-mesin pencari informasi macam Google dan Yahoo sebagai sebuah jawaban terhadap keinginan untuk menghadirkan informasi setiap saat kepada siapa pun yang mengaksesnya, pada satu sisi 
telah menyebabkan telah memudahkan kehidupan. Namun pada sisi lain ternyata hal itu juga menyebabkan orang dapat mengakses informasi apa saja, dan menelannya tanpa upaya untuk bersikap selektif terhadap informasi tersebut. Digitalisasi komunikasi mendorong setiap orang untuk mampu memproduksi dan mencerna informasi maupun berita melalui media digital (Aribowo, 2017) Dengan kata lain, kemampuan literasi media merupakan prasyarat bagi setiap individu yang ingin terjun dalam lautan informasi saat ini.

Dalam konteks kewarganegaraan, Milner (2002) menyatakan bahwa kemampuan literasi media merupakan salah satu kompetensi dari literasi kewarganegaraan (civic literacy). Mengenai keterkaitan pentingnya pendidikan Kewarganegaraan mendidik warga negara muda memiliki kemelekan (literacy) di abad 21, Nussbaum (Banks, 2008) mengutarakan bahwa Pendidikan Kewarganegaraan harus membantu siswa mengembangkan identitas dan keterikatan pada komunitas global dan hubungan manusia kepada orang lain di seluruh dunia. Pendidikan kewarganegaraan memiliki peran penting dalam membangun generasi muda menjadi warga negara yang cerdas dan baik (smart and good citizen).

Dunia digital saat ini membawa dampak yang luar biasa mengubah pola dalam pergaulan. Kekuatan media sosial misalnya berpengaruh terhadap partisipasi warga negara muda di Amerika. Hasil survey McArthur Foundation Research Network on Participatory Politic bahwa $41 \%$ pemuda berusia 15 hingga 25 tahun telah berpartisipasi dalam kelompok politik baru secara online, menulis dan menyebarluaskan blog tentang isu politik dan video politik di media sosial mereka (Kahne \& Middaugh, 2012). Hal ini menunjukkan kekuatan media sosial online mempengaruhi partisipasi politik warga negara muda. Kondisi tersebut diperkuat oleh penelitian Martens \& Hobbs (2015, hal. 120) bahwa "...students in a selective-admission media literacy program have substantially higher levels of media knowledge and news and advertising analysis skills than other students. Participation in a media literacy program was positively associated with information-seeking motives, media knowledge, and news analysis skills. Moreover, information-seeking motives, media knowledge, and news analysis skills independently contributed to adolescents' intent toward civic engagement" Artinya bahwa ada hubungan antara literasi media dengan peningkatan pengetahuan dan civic engagement warga negara muda dan berkontribusi terhadap civic engagement mereka ketika dewasa. Oleh sebab itu kecakapan melakukan komunikasi dengan menggunakan berbagai perangkat teknologi komunikasi yang canggih perlu didukung oleh kecakapan literasi yang memadai oleh penggunanya. Prinsipnya hi-tech perlu didukung oleh hi-touch.

Di era demokratisasi saat ini yang bercirikan adanya kebebasan berpendapat setiap warga baik secara lisan ataupun tertulis, maka fenomena hoax menjadi satu hal yang harus menjadi perhatian bersama. Adapun hoax dapat dalam bentuk, ide palsu (false idea), prinsip yang bertentangan (offence principle), manipulasi media (media manipulation), keseimbangan (balancing), objektivitas (objectivity), melawan netralitas moral (against moral neutrality) (CohenAlmagor, 2010). Adapun ide palsu hanya dapat dibuktikan melalui hasil yang konkret yang merusak. Prinsip yang bertentangan antara kebebasan dan toleransi tidak pernah dapat dipertemukan. Namun ide palsu yang menimbulkan pernyataan kebencian dan dapat merusak tatanan sosial sehingga, itu harus dikeluarkan dari kebebasan berpendapat.

Hoax umumnya disebarkan melalui media online seperti email, Facebook, Tweeter, berita online, dan lain-lain. Kata hoax berasal dari "hocus pocus" yang aslinya adalah bahasa Latin "hoc est corpus", artinya "ini adalah tubuh". Kata ini biasa digunakan penyihir untuk mengklaim bahwa sesuatu adalah benar, padahal belum tentu benar. Hoax bertujuan untuk membuat opini publik, menggiring opini publik, membentuk persepsi juga untuk huffing fun yang menguji kecerdasan dan kecermatan pengguna internet 
dan media sosial, dan pada umumnya hoax disebarkan sebagai bahan lelucon atau sekadar iseng, menjatuhkan pesaing (black campaign), promosi dengan penipuan, ataupun ajakan untuk berbuat amalan-amalan baik yang sebenarnya belum ada dalil yang jelas di dalamnya (Rahadi, 2017). Namun ini menyebabkan banyak penerima hoax terpancing untuk segera menyebarkan kepada rekan sejawatnya sehingga akhirnya hoax ini dengan cepat tersebar luas. Kata hoax didasarkan pada sebuah film yang berjudul The Hoax yang banyak mengandung kebohongan dikarenakan plot naskah tidak sesuai dengan novel aslinya. Fenomena hoax pada era pasca kebenaran batas antara ucapan yang benar dan dusta, antara kebenaran dan keculasan, antara fiksi dan non fiksi, jadi kabur (Muhammad, 2017) . Ditambahkannya di era pasca kebenaran kita hidup di sebuah lingkungan yang tak menyediakan cukup penangkal kecenderungan kita mengelabui orang lain (Muhammad, 2017). Dalam konteks kewarganegaraan, Milner mengatakan bahwa kemampuan melek media adalah salah satu kompetensi melek huruf kewarganegaraan. Sebagai persyaratan kompetensi kewarganegaraan, kemampuan membaca media dalam keterampilan komunikasi, tanggung jawab dalam korespondensi merupakan kebutuhan setiap warga negara, sehingga dalam melaksanakan kegiatan pemanfaatan ruang publik menjadi lebih bijak, etis, dan bertanggung jawab (Milner, 2002).

Tingkat keterampilan dan keaksaraan yang rendah di era digital menyebabkan penggunaan teknologi yang tidak kompeten, penggunaan teknologi yang berpotensi tidak bertanggung jawab. Untuk itu diperlukan kompetensi dalam pemanfaatan teknologi yang dikenal dengan nama digital literacy (McGonagle, 2011). Keaksaraan digital adalah kemampuan untuk: a) menggunakan teknologi secara kompeten, b) memahami dan menafsirkan konten digital dan mengukur kredibilitasnya, c) menciptakan, meneliti, dan berkomunikasi dengan alat yang sesuai dan tepat (Common Sense Media, 2009). Program keaksaraan digital merupakan elemen penting dalam pendidikan media dan melibatkan alat pembelajaran dasar dan kurikulum untuk keterampilan berpikir kritis dan kreatif. Keaksaraan digital ini menjadi bagian penting dari kewarganegaraan, sehingga warga yang bercita-cita menjadi warga negara yang cerdas dan bertanggung jawab dapat tercapai. Peningkatan literasi media menjadi hal yang mutlak dilakukan agar masyarakat mampu mengenali dan memahami konten yang disampaikan media sehingga mampu menentukan apakah sebuah informasi tersebut merupakan hoax atau bukan (Aribowo, 2017).

Di era demokratisasi saat ini kebebasan berpendapat setiap warga negara secara lisan atau tulisan, maka fenomena tipuan menjadi satu hal yang seharusnya menjadi perhatian bersama. Di era demokratisasi saat ini kebebasan berpendapat setiap warga negara secara lisan atau tulisan, maka fenomena hoax menjadi satu hal yang harus menjadi perhatian bersama (Bennett, 2008). Tipuan tersebut bisa berupa gagasan palsu, prinsip ofensif, manipulasi media, keseimbangan, objektivitas, terhadap netralitas moral (Cohen-Almagor, 2010). Gagasan palsu bisa dibuktikan melalui hasil nyata yang menghancurkan. Prinsip kebebasan dan toleransi yang bertentangan tidak akan pernah bisa didamaikan, akan tetapi ide palsu yang menghasilkan ucapan kebencian dan bisa merusak tatanan sosial sehingga harus dikeluarkan dari kebebasan berekspresi (Haryanto, 2017).

Kesimpulan penelitian Rahadi (2017) menunjukkan bahwa media sosial merupakan media yang paling banyak dimanfaatkan orang untuk melakukan penyebaran berita bohong, dan bermacam motivasi orang untuk melakukan penyebaran berita bohong diantaranya adalah: mengubah opini publik, supaya menjadi viral di media sosial, ingin mengubah kebijakan pemerintah yang dirasa tidak sesuai, ingin menghakimi atau mencela perbuatan personal yang melanggar hukum, mendukung elemen masyarakat tertentu, persaingan bisnis, minimnya tindakan hukum.

Pada level perguruan tinggi penting untuk diketahui persepsi mahasiswa terhadap maraknya fenomena penyebaran berita 
bohong/berita palsu di berbagai media sosial. Dari hasil pengamatan dan wawancara secara sporadis dengan teman-teman di kampus karena mahasiswa tahun-tahun awal pada umumnya adalah pelaku aktif dalam komunikasi virtual melalui internet, sebab mereka adalah digitally native di era informasi digital ini. Sebagai pelaku aktif maka perlu diketahui apakah secara umum mahasiswa mampu mengenali sebuah berita itu merupakan berita palsu atau berita bohong. Dengan kemampuan untuk mengenali suatu berita adalah hoax maka tentunya mereka memiliki keterampilan untuk menangkalnya.

\section{Metode}

Desain penelitian yang digunakan adalah penelitian survei. Penelitian survei dimaksudkan untuk mengumpulkan data sebanyak-banyaknya, biasanya dimaksudkan sebagai penelitian pendahuluan untuk ditindaklanjuti dengan upaya lain (Arikunto, 2013). Dalam penelitian survei, peneliti meneliti karakteristik dari atau hubungan sebab antar variabel tanpa intervensi dari peneliti.

Pengambilan sampel dilakukan secara acak (random) dengan persentase 10-12\% dari seluruh mahasiswa FISH angkatan 2017 yaitu 856 orang. Dengan demikian akan terdapat 80-120 orang mahasiswa yang akan menjadi sampel penelitian. Untuk mengumpulkan data lapangan digunakan teknik kuesioner (angket). Jenis kuesioner yang digunakan adalah kuesioner tertutup. Variabel penelitian ini hanya satu yakni "persepsi mahasiswa FISH terhadap kemunculan berita bohong" di media sosial (medsos) di internet. Untuk menganalisis data (statistik) yang telah diperoleh dari lapangan maka digunakan analisis statistik deskriptif dalam bentuk teknik analisis persentase (\%), rata-rata (rerata), maupun median atau titik tengah. Sedangkan untuk menganalisis data kualitatif digunakan analisis kualitatif dengan pendekatan rasional.

\section{Hasil dan Pembahasan}

Jumlah sampel berdasarkan gender sejumlah $16 \%$ berjenis kelamin laki-laki, sedangkan $84 \%$ jenis kelamin perempuan pengguna media sosial secara aktif. Dengan melihat grafik 1 di bawah ini, dari $85,2 \%$ responden yang memberikan jawaban "selalu" menggunakan media sosial. Penggunaan media sosial ini terkait dengan pola perilaku konsumen dalam memilih suatu produk yang dibagi ke dalam lima kategori: functional value, social value, emotional value, epistemic value, and conditional value (Hallikainen, 2015; Sheth, Newman, \& Gross, 1991). Berdasarkan survei dari We Are Social terungkap bahwa orang Indonesia menghabiskan waktu sebanyak 3 jam 23 menit untuk menggunakan media sosial (Kemp, 2018, hal. 58). Dalam penelitian ini tidak dikemukakan motivasi penggunaan media sosial.

Sebanyak $86,4 \%$ responden mengakui bahwa dirinya "selalu "mendapatkan beritaberita melalui media sosial, sedangkan sisanya $13,6 \%$ menjawab "jarang "mendapatkan berita-berita melalui media sosial. Penggunaan media sosial untuk mendapatkan berita baru masuk dalam kategori epistemic, yakni kemampuan platform media sosial untuk membangkitkan keingintahuan, memberikan kebaruan atau pengetahuan (Hallikainen, 2015; Sheth et al., 1991). Responden juga mengaku mengetahui bahwa selama ini pemerintah "selalu" memberikan peringatan kepada masyarakat tentang bahayanya berita hoax. Hal ini didukung oleh $53,1 \%$ responden. Sedangkan $43,2 \%$ responden menjawab "jarang" mengetahui bahwa pemerintah mengingatkan masyarakat tentang bahaya hoax. Selanjutnya $76,5 \%$ responden menjawab" selalu" merespon positif peringatan pemerintah tersebut, dan hanya 3,7\% responden saja yang menjawab "tidak pernah" merespon positif. Dengan demikian, respons yang positif menjadi penting karena munculnya berita hoax ini sangat berbahaya karena menyebarkan kebohongan dengan memiliki konten palsu secara sengaja, bermotif keuangan, dan dimaksudkan oleh penciptanya untuk menipu (Verstraete, Bambauer, \& Bambauer, 2017). 
Sebanyak 2,5\% responden menjawab "tidak pernah" menaati saran dan peringatan dari pemerintah tentang bahaya hoax, dan hanya $56,8 \%$ responden yang menjawab "selalu "menaati saran dan peringatan tersebut. Sementara sisanya $40,7 \%$ jarang mentaati saran dan peringatan tersebut. Oleh akrena itu, harus diwaspadai bawah ada lebih dari 40 persen responden yang malas menaati peringatan pemerintah tersebut, padahal penggunaan media sosial, termasuk blog telah berkembang secara eksponensial di Indonesia. Akibat dari penggunaan media sosial yang besar itu, lanskap sosial dan politik berubah, yakni dalam hal penggunaan untuk kampanye politik untuk mendapatkan suara, dan yang berbahaya adalah untuk mengeksploitasi pidato kebencian (Noonan \& Platt, 2015).

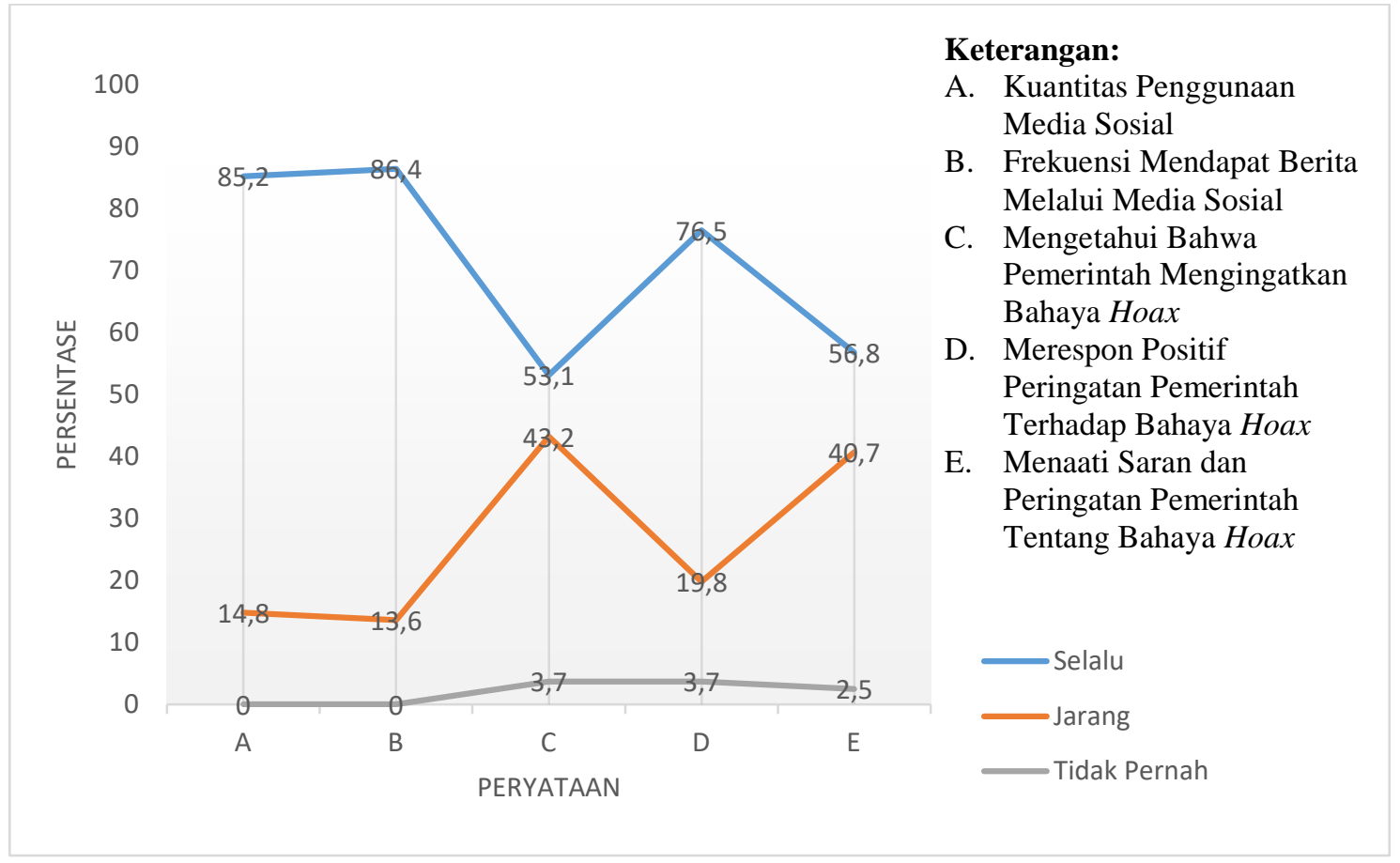

Grafik 1. Media sosial dan hoax

Kemunculan berita-berita hoax akhirakhir ini sangat massif terjadi. Sebagaimana dapat dilihat pada grafik 2 di bawah, sekitar $29,6 \%$ responden mengakui sering kali mendapatkan berita-berita Hoax, khususnya berita-berita yang menyinggung masalah Suku, Agama, Ras, dan Antar Golongan (SARA). Sedangkan $67,9 \%$ mengatakan jarang mendapatkan berita-berita hoax tentang Sara di media sosial, sisanya $2,5 \%$ responden bahkan mengatakan tidak pernah mendapatkan berita-berita hoax tentang sara. Akan tetapi, 82,7\% responden dalam penelitian ini, mengakui bahwa berita hoax tentang sara merupakan berita yang sangat berbahaya, sehingga dapat menimbulkan kebencian ataupun konflik ditengah-tengah masyarakat, dan mereka sadar akan bahayanya menyebarkan berita hoax. Sedangkan $17,3 \%$ responden mengatakan jarang memiliki kesadaran akan bahayanya berita hoax.

Responden secara keseluruhan memiliki kesadaran akan bahayanya berita hoax, yang membedakan adalah tingkat kesadarannya, yaitu ada yang kadang-kadang sadar, namun ada juga yang selalu waspada dan sadar bahayanya berita hoax. Diketahui bahwa hanya $9,9 \%$ responden yang tidak pernah marah saat membaca berita hoax, sedangkan 42\% mengaku jarang menyikapi berita hoax dengan sikap marah, sisanya $48,1 \%$ mengaku marah saat membaca berita hoax. Perubahan pola komunikasi yang terjadi dalam masyarakat saat ini di dunia maya sejatinya memberikan pola dan dampak baru dalam kehidupan masyarakat modern. Apabila selama ini pola komunikasi yang telah mapan terdiri dari pola one-to-many audiences atau dari satu sumber ke banyak pemirsa (seperti 
buku, radio, dan televisi), dan pola one- toone audience dari satu sumber ke satu pemirsa atau (seperti telepon dan surat), maka pola komunikasi masyarakat siber menggunakan kombinasi pola 'many- to-many' dan pola 'few-to-few' (Juliswara, 2017). Pergeseran yang terjadi misalnya beberapa waktu belakangan ini terjadi perubahan mengenai penggunaan media informasi dan juga pencarian referensi. Tren membaca buku cetak, majalah cetak dan media lainnya tampak tergantikan dengan media online (Arpannudin, 2016)

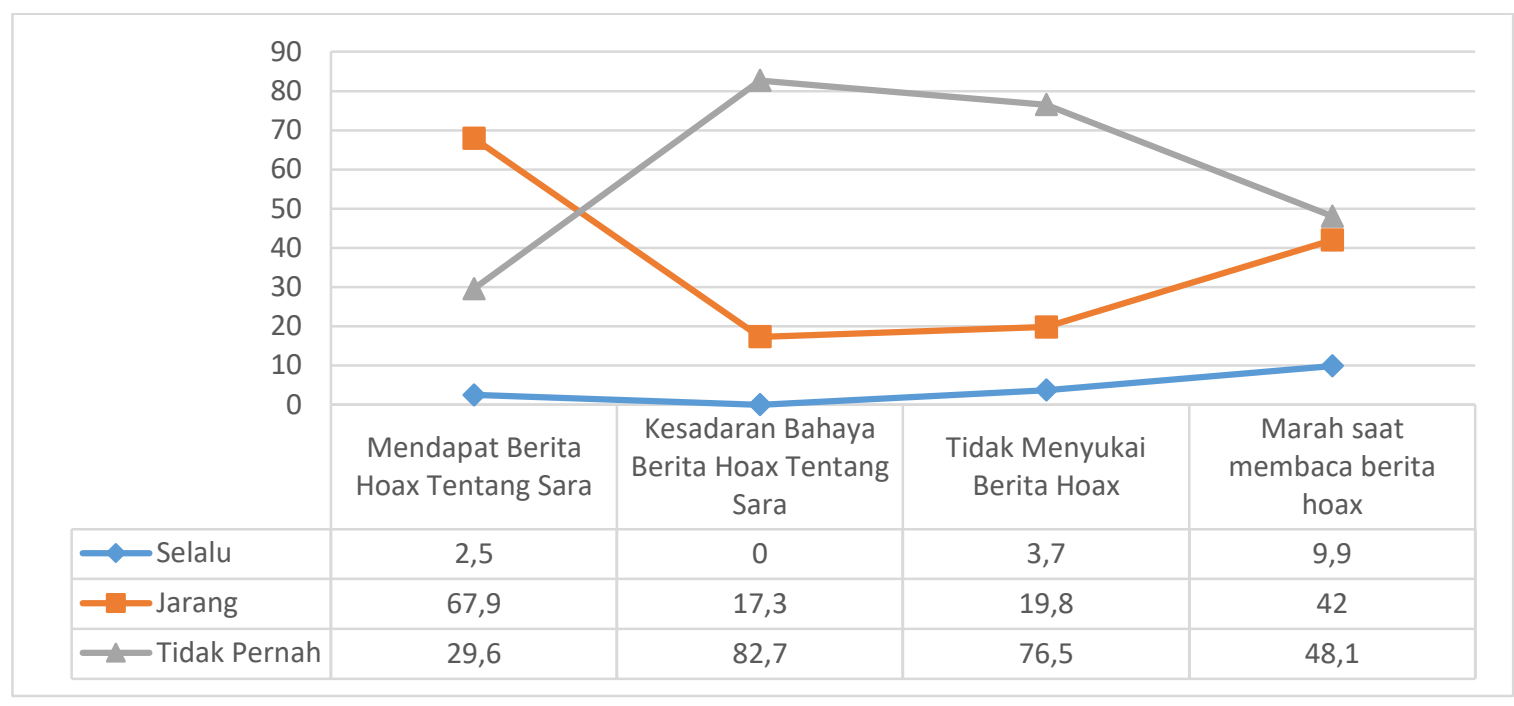

Grafik 2. Respons mahasiswa terhadap berita hoax

Dari data ditemukan bahwa 91,4\% responden "selalu" menganggap bahwa hoax adalah pembodohan kepada masyarakat, sedangkan $6,2 \%$ responden menjawab "jarang" yang menganggap hoax adalah pembodohan kepada masyarakat, sisanya 2,5\% menjawab "tidak pernah" menganggap hoax adalah pembodohan kepada masyarakat. Ketika ditanya tentang reaksi responden ketika mendapati berita hoax, mereka mengaku kerap kali melakukan sesuatu agar berita hoax tersebut tidak menyebar dengan luas dan dipercaya dengan mudah oleh masyarakat. 54,3\% responden yang menjawab "jarang" melakukan sesuatu untuk melawan hoax. Sedangkan 9,9\% responden bahkan menjawab "tidak pernah" melakukan sesuatu untuk melawan hoax, dan hanya sekitar 35\% responden yang menjawab "selalu" melakukan sesuatu untuk melawan berita hoax yang tersebar di media sosial. Respons yang bagus tentang hoax ini merupakan salah satu kontribusi dari civic literasi dan digital citizenship yang berkaitan dan kemelekan warga negara ini pada akhirnya ada pemahaman warga negara dalam proses politik dan pemerintahan, lokal dan nasional yang mengerti hak dan kewajibannya dan selalu berpartisipasi secara efektif dalam kehidupan bermasyarakat lokal, nasional dan internasional. Civic literacy meliputi pengetahuan mengenai pemerintahan dan peran warganegara seperti civic disposition, civic knowledge dan partisipasi warga negara. Civic literacy ini mutlak dimiliki oleh setiap warga negara muda sebagai bekal untuk mewujudkan warga negara abad 21 ini. Digital citizenship meliputi warga negara yang memiliki pengetahuan dan keterampilan dalam dunia digital saat ini, berperan serta dalam dunia tersebut dan bertanggung-jawab atas pilihannya dalam dunia maya tersebut. Secara lebih singkat, Mossberger, Tolbert, \& McNeal (2008, hal. 1) mengutarakan "digital citizenship is the ability to participate in society online". Ini berarti bahwa kemelekan terhadap dunia online menjadikan modal yang sangat penting dalam pergaulan warga negara muda dalam dunia digital saat ini dan juga untuk menangkal hoax

Berdasarkan hasil perhitungan distribusi frekuensi, rata-rata responden tidak langsung menyebarkan ulang berita-berita yang mereka baca. $37 \%$ responden mengatakan menjawab 
"tidak pernah" menyebarkan ulang beritaberita yang mereka baca di media sosial, dan $59,3 \%$ responden menjawab "jarang" menyebarkan ulang berita-berita yang mereka baca. Sedangkan 3,7\% menjawab "selalu" menyebarkan atau ulang setiap berita yang mereka baca di media sosial. Ada beberapa kiat untuk menghalau berita palsu atau hoax di media sosial maupun di internet pada umumnya, yakni: (1) periksa sumbernya, kenali situs lebih dalam, periksa misi dan siapa pengelola informasinya; (2) baca yang tersirat, judul bisa bombastis, akan tetapi penting untuk membaca seluruh isi berita; (3) periksa penulisnya, cari tahu siapa penulisnya; (4) sumber pendukung, klik tautan pendukung berita. Pastikan apakah benar mendukung berita; (5) periksa tanggalnya, mengunggah berita lama bisa saja sudah tidak relevan dengan peristiwa saat ini; (6) apakah lelucon? Bila terasa janggal, mungkin hanya sindiran, periksa situs dan penulisnya; (7) hindari prasangka. Pertimbangkan bahwa keyakinanmu dapat mempengaruhi penilaian; dan (8) tanya kepada pakar, tanyakan kepada pustakawan atau periksa ke situs pengujian fakta (IFLA, 2018).

Menyoal perihal check and recheck, bahwa responden yang menjawab "tidak pernah" cross check berita memang tidak ada, dan sekitar 45,7\% responden yang menjawab "jarang" memeriksa kembali berita di media sosial. Sedangkan 54,3\% menjawab "selalu" melakukan check dan recheck berita yang mereka baca. Beberapa responden juga ada yang mengaku tidak pernah diingatkan oleh orang lain tentang bahaya berita hoax, ada juga yang jarang diingatkan oleh orang lain, serta ada juga yang mengaku selalu diingatkan orang lain tentang bahayanya berita hoax. $7,4 \%$ responden yang menjawab "tidak pernah" diingatkan orang lain perihal bahaya berita hoax, sedangkan 50,6\% menjawab "jarang" diingatkan oleh orang lain tentang bahaya hoax. Sementara itu hanya $42 \%$ saja responden yang menjawab "selalu" diingatkan orang lain tentang bahaya hoax. Selain itu, 6,2\% responden menjawab "tidak pernah" mengingatkan orang lain tentang bahaya penyebaran berita hoax, dan ada $48,1 \%$ responden yang menjawab "jarang" mengingatkan orang lain tentang bahaya berita hoax. Hanya sekitar $45,7 \%$ saja responden yang menjawab "selalu" mengingatkan orang lain tentang bahaya berita hoax.

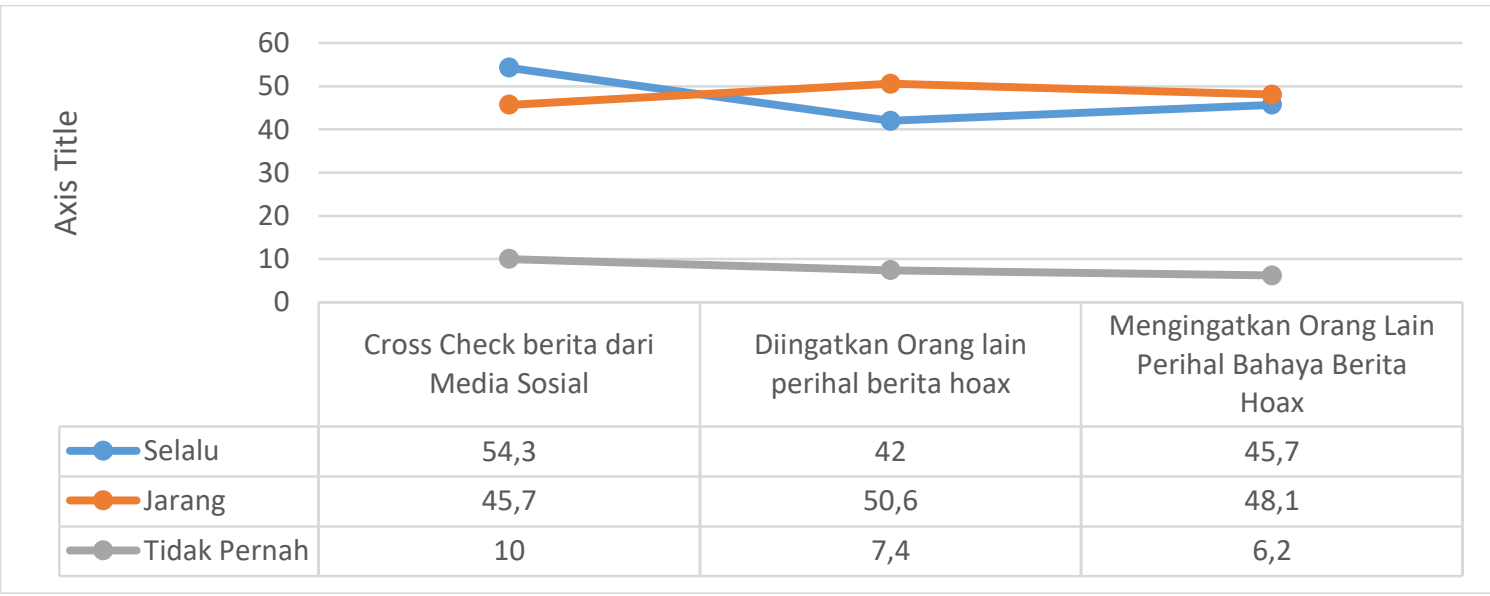

Grafik 3. Respon terhadap berita hoax

Sebagaimana telah dipaparkan di atas bahwa responden dalam penelitian ini adalah mahasiswa FISH Universitas Negeri Surabaya angkatan 2017, itu artinya responden dalam penelitian ini adalah mahasiswa baru yang mayoritas berusia kira-kira antara 17-20 tahun. Responden dalam penelitian ini terdiri dari dua jenis kelamin, laki-laki dan perempuan. Kedua jenis kelamin tersebut distribusi nya tidak seimbang, $84 \%$ perempuan, dan hanya $16 \%$ laki-laki. Hal tersebut menunjukkan bahwa hasil penelitian 
ini juga bisa digunakan untuk menganalisa perilaku mahasiswi terhadap hoax di media sosial.

Sementara itu, dalam penggunaan media sosial kaum perempuan lebih aktif dari pada laki-laki, sehingga bisa disimpulkan proses penyebaran berita dalam media sosial banyak melibatkan kaum perempuan. Artinya adalah bahwa kaum perempuan bisa dinilai dapat menjadi faktor dalam proses penyebaran berita-berita hoax. Responden dalam penelitian ini, bisa dipastikan secara keseluruhan memiliki akun media sosial. Hal ini ditunjukkan dari 85,2\% responden yang memberikan jawaban "selalu" menggunakan media sosial, sedangkan $14,8 \%$ menjawab "jarang "menggunakan media sosial. Hal ini menunjukkan bahwa sampel dalam penelitian ini sangat valid. Di samping itu, responden juga mengaku selalu mendapati dan membaca berita-berita di media sosial, pendapat ini didukung oleh $86,4 \%$ responden, sedangkan sisanya $13,6 \%$ menjawab "jarang" mendapatkan berita-berita melalui media sosial. Artinya seluruh sampel atau responden dalam penelitian ini pernah mendapatkan dan membaca berita melalui media sosial, ini juga membuktikan validitas sampel dalam penelitian ini.

Secara umum dapat dinyatakan bahwa penyebaran berita bohong yang marak terjadi ini jika dikaitkan dengan etika pada internet adalah pengingkaran terhadap prinsip-prinsip kebebasan universal yang telah digaungkan beberapa dekade yang lalu. Prinsip dan etika yang dimaksud adalah prinsip kebebasan berbicara (freedom of speech). Prinsip ini berasal dari negara-negara yang memiliki tradisi liberal yang menjamin kebebasan tiap warganegara untuk mengemukakan kebebasan dalam menyatakan pendapat baik lisan maupun tertulis. Namun demikian kebebasan tersebut diikuti dengan pedoman normatif yang membatasi kebebasan tersebut terutama jika dikaitkan dengan kebebasan orang lain. Untuk itu jika seseorang dalam komunikasi di media sosial terlalu memuji seseorang, menyalahkan orang lain, menghasut, menghujat serta mencemarkan nama baik orang lain maka hal itu dipandang sebagai perbuatan melawan hukum. Karena pemanfaatan internet bersifat lintas negara, dapat diduga bahwa perbedaan dan bias budaya antar negara juga mempengaruhi cara orang memanfaatkan era kebebasan berbicara ini. Pada lingkup perpaduan antara kehidupan dan pengetahuan tentang literasi media ini melihat bahwa seorang yang melek media dapat menginterpretasikan, menganalisis, dan memproduksi pesan melalui media (Potter, 2009). Hal ini sejalan dengan tujuan literasi media adalah untuk menghasilkan warga masyarakat yang "well informed" serta dapat membuat penilaian terhadap content media berdasarkan pengetahuan dan pemahaman mereka terhadap media yang bersangkutan (Potter, 2009). Literasi media mempunyai konsep memfasilitasi khalayak konsumen media (publik) untuk berbudaya dalam memanfaatkan media sosial.

\section{Simpulan}

Secara umum mahasiswa Fakultas Ilmu Sosial dan Hukum Universitas Negeri Surabaya memiliki persepsi positif terhadap penyebaran berita bohong di media sosial. Dalam pandangan mereka, jika penyebaran berita hoax tidak dicegah oleh pemerintah, maka hal ini akan mengancam integrasi nasional. Sebagian besar mahasiswa menyadari bahwa maraknya penyebaran berita hoax di media sosial merupakan satu bentuk pembodohan masyarakat, namun demikian hanya sepertiga dari responden yang diteliti yang selalu melakukan perlawanan terhadap kemunculan berita hoax dengan cara melakukan tindakan perlawanan, sedangkan sisanya tidak melakukan apa-apa untuk melawan berita hoax. Pada akhirnya, perlunya gerakan literasi bagi mahasiswa baru melalui berbagai kegiatan membaca yang ada di setiap program studi, jurusan maupun fakultas. Peningkatan kualitas literasi mahasiswa merupakan senjata yang ampuh bagi penajaman kemampuan berfikir kritis mereka sehingga mereka akan dengan mudah mengenali berita bohong di media sosial. 


\section{Ucapan Terima Kasih}

Terima kasih penulis haturkan kepada para Dekan Fakultas Ilmu Sosial dan Hukum Universitas Negeri Surabaya yang telah memberikan bantuan dana penelitian dalam penelitian ini.

\section{Referensi}

Aribowo, E. K. (2017). Menelusuri jejak hoaks dari kacamata bahasa: Bagaimana mendeteksi berita palsu sedini mungkin. In Literasi dalam Pembelajaran Bahasa (hal. 78-87).

Arikunto, S. (2013). Prosedur penelitian. Suatu pendekatan praktek (15 ed.). Jakarta: Rineka Cipta.

Arpannudin, I. (2016). Literasi warga negara muda untuk pengembangan civic engagement di abad 21. In Sapriya, Syaifullah, S. Fitriasari, L. Anggraeni, D. Iswandi, D. I. Muthaqin, ... R. Yudistira (Ed.), Prosiding Seminar Pendidikan Kewarganegaraan sebagai Bidang Ilmu dan Program Pendidikan dalam Konteks Penguatan Daya Saing Lulusan. Bandung: Labratorium Pendidikan Kewarganegaraan Universitas Pendidikan Indonesia.

Banks, J. A. (2008). Diversity, group identity, and citizenship education in a global age. Educational Reseacrh, 37(3), 129-139.

Bennett, W. L. (2008). Changing citizenship in the digital age. In W. L. Bennett (Ed.), Civic life online: Learning how digital media can engage youth (Vol. , hal. 1-24). Cambridge: The MIT Press. https://doi.org/10.1162/dmal.9780262524 827.001

Cohen-Almagor, R. (2010). Responsibility of and Trust in ISPs. Knowledge, Technology \& Policy, 23(3-4), 381-397. https://doi.org/10.1007/s12130-0109119-3

Common Sense Media. (2009). Digital literacy and citizenship in the 21st century. San Francisco: Common Sense Media.

Hallikainen, P. (2015). Why people use social media platforms: Exploring the motivations and consequences of use. In L. Mola, F. Pennalrola, \& S. Za (Ed.), From information to smart society enviroment, politics, and economics (hal.
9-17). Switzerland: Springer International Publishing. https://doi.org/10.1007/978-3-31909450-2

Haryanto, I. (2017). Imbangi hoaks dengan tradisi baca. Diambil 28 Mei 2018, dari https://kompas.id/baca/opini/2017/09/14/ imbangi-hoaks-dengan-tradisi-baca/

IFLA. (2018). Mengenali informasi palsu. https://www.ifla.org/publications/node/1 $1174 . \quad$ Diambil dari https://www.ifla.org/files/assets/hq/topics /info-society/images/indonesian__how_to_spot_fake_news.pdf

Juliswara, V. (2017). Mengembangkan model literasi media yang berkebhinekaan dalam menganalisis informasi berita palsu (hoax) di media sosial. Jurnal Pemikiran Sosiologi, 4(2), 142-164. https://doi.org/https://doi.org/10.22146/jp s.v4i2.28586

Kahne, J. ., \& Middaugh, E. (2012). Digital media shapes youth participation in politics. $P h i$ Delta Kappan, 94(3), 52-56. https://doi.org/10.1177/00317217120940 0312

Kemp, S. (2018). Digital in 2018. Essential insights of internet, social media, mobile, and ecomemmerce use around the world. We Are Social.

Martens, H., \& Hobbs, R. (2015). How media literacy supports civic engagement in a digital age. Atlantic Journal of Communication, 23(2), 120-137. https://doi.org/10.1080/15456870.2014.9 61636

McGonagle, T. (2011). Media literacy : No longer the shrinking violet of European audiovisual media regulation? In Media Law and Policy (hal. 187-212).

Milner, H. (2002). Civic literacy: How informed citizens make democracy work. Hanover, NH: University Press of New England.

Mossberger, K., Tolbert, C. J., \& McNeal, R. S. (2008). Digital citizenship. The internet, society, and participation. Cambridge, Massachusetts London, England: The MIT Press.

Muhammad, G. (2017). Universitas dan pasca kebenaran. Surakarta: Universitas Sebelas Maret. 
Noonan, C., \& Platt, A. (2015). Global social media directory. Pacific Northwest National Laboratory. Washington. Diambil dari http://www.pnnl.gov/main/publications/e xternal/technical_reports/PNNL23805rev1.pdf

Potter, W. J. (2009). Media literacy. In W. F. Eadie (Ed.), 21st Century Communication: A Reference Handbook (hal. 558-570). London; California; New Delhi; Singapore: Sage Publications, Inc.

Rahadi, D. R. (2017). Perilaku pengguna dan informasi hoax di media sosial. Jurnal Manajemen dan Kewirausahaan, 5(1), 58-70.

Sheth, J. N., Newman, B. I., \& Gross, B. L. (1991). Why we buy what we buy: A theory of consumption values. Journal of business research, 22(2), 159-170.

Verstraete, M., Bambauer, D. E., \& Bambauer, J. R. (2017). Identifying and countering fake news. Arizona. https://doi.org/10.1016/j.najef.2017.08.0 12 